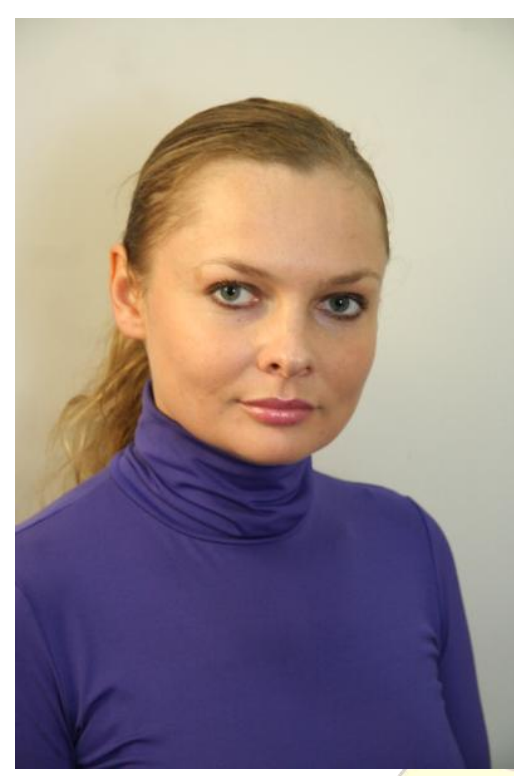

ПРАВОВІ ПІДСТАВИ ВІДСТУПУ УКРАЇНИ ВІД ОКРЕМИХ ЗОБОВ'ЯЗАНЬ, ВИЗНАЧЕНИХ МІЖНАРОДНИМ ПАКТОМ ПРО ГРОМАДЯНСЬКІ І ПОЛІТИЧНІ ПРАВА ТА КОНВЕНЦІЕ ПРО ЗАХИСТ ПРАВ ЛЮДИНИ І ОСНОВОПОЛОЖНИХ СВОБОД

\author{
Чевичалова Жанна В'ячеславівна, \\ канд. юрид. наук, \\ дочент кафедри міжнародного права, \\ Начіональний юридччний університет \\ імені Ярослава Мудрого, \\ Україна, м. Харків \\ e-mail: zhannachevychalova@gmail.com \\ ORCID 0000-0001-9320-9441
}

Розглянуто правові підстави відступу України від окремих зобов'язань, визначених Міжнародним пактом про громадянські і політичні права та Конвенцією про захист прав людини і основоположних свобод, а також його відповідність вимогам, щуо випливають $з$ Конвениії та практики Свропейського судуз прав людини.

Ключові слова: захист прав людини; відступ держави від зобов'язань під час суспільної небезпеки; право на дерогацію.

Постановка проблеми. Сучасні міжнародні договори про права людини можуть передбачати право держав, що беруть у них участь, на відступ від виконання договірних зобов'язань за умови надзвичайних обставин. Наявність права на дерогацію (заснованого на нормах закону права держави відступати від виконання певних договірних зобов'язань) суттєво впливає на поведінку держави у галузі забезпечення і захисту прав людини.

Аналіз останніх досліджень і публікацій. 21 травня 2015 р. Україна використала таке право як учасниця Конвенції про захист прав людини i основоположних свобод (далі - Конвенція), ст. 15 якої закріплює право на відступ від зобов’язань під час суспільної небезпеки, що зумовило приділення науковцями більш пильної уваги дослідженню питання права на дерогацію. Зокрема, зазначене питання вивчали у своїх працях М. М. Гнатовський, В. Н. Русинова та Г. О. Христова.

Знайомство з роботами цих та інших авторів дає підстави дійти висновку, 
що в доктрині міжнародного права існують два протилежних розуміння призначення права відступу від зобов’язань під час надзвичайної ситуації. Прихильники першого розуміють такий відступ як безумовно недобросовісний акт держави, відповідно до другого підходу право на дерогацію розглядається як пошук балансу між захистом індивідуальних прав людини і державним інтересом. Слід зазначити, що закріплення такого права держави у ключових міжнародних договорах 3 прав людини як регіонального, так і універсального характеру, свідчить про те, що право на відступ від зобов’язань під час надзвичайної ситуації слід розглядати в рамках другого підходу. При цьому, однак, на перший план виходять контрольний механізм запобігання зловживанню правом, а також розроблення критеріїв оцінки добросовісності поведінки держави.

Виклад основного матеріалу. 5 червня 2015 p. Україна повідомила Генерального секретаря Ради Європи про те, що, беручи до уваги надзвичайне становище у державі, влада України вирішила використати ст. 15 Конвенції для відступу від деяких прав, закріплених у Конвенції. Обов’язковість такого повідомлення міститься у ч. 3 зазначеної статті. Як і положення щодо обов’язковості інформування Генерального секретаря Ради Свропи, так i розуміння поняття надзвичайної ситуації було сформульовано за підсумками тривалих дискусій між учасниками Конвенціі. На універсальному рівні вироблення єдиного розуміння поняття надзвичайного становища потребувало ще більших зусиль.

Поняття надзвичайного становища за п. 1 ст. 4 Міжнародного пакту про громадянські і політичні права (далі - Пакт) є аналогічним до сформульованого у п. 1 ст. 15 Конвенції. Відповідно до першого, під час надзвичайного становища в державі, при якому життя нації перебуває під загрозою і про наявність якого офіційно оголошується, держави-учасниці цього Пакту можуть вживати заходів на відступ від своїх зобов'язань за цим Пактом тільки і в такій мірі, в якій це диктується гостротою становища, за умови, що такі заходи не $є$ несумісними з їх іншими зобов'язаннями за міжнародним правом і не тягнуть 
за собою дискримінації виключно на основі раси, кольору шкіри, статі, мови, релігії чи соціального походження.

У свою чергу, п. 1 ст. 15 Конвенції закріплює, що під час війни або іншої суспільної небезпеки, яка загрожує життю нації, будь-яка Висока Договірна Сторона може вживати заходів, що відступають від іiі зобов’язань за цією Конвенцією, виключно в тих межах, яких вимагає гострота становища, i за умови, що такі заходи не суперечать іншим їі зобов’язанням згідно 3 міжнародним правом.

Така схожість є цілком виправданою, оскільки створює певне уніфіковане розуміння надзвичайного становища, що є необхідним 3 огляду на те, що зазначені норми на відміну від загальної спрямованості цих документів не забезпечують, а обмежують права людини.

Як відомо, вперше пропозиція про внесення до міжнародного договору 3 прав людини положення про відступ від зобов'язань стосувалася Пакту. Таку пропозицію подала Велика Британія до Редакційного комітету Комісії 3 прав людини Організації Об'єднаних Націй у червні 1947 р. Дискусії точилися навколо кожного поняття, що становило б правову норму про відступ від деяких зобов'язань за договором. Зазначені дискусії плідно вплинули на теоретичний аспект захисту прав людини у надзвичайному становищі. Свободу дій держав у цій галузі було обмежено такими принципами:

- виключної загрози;

- офіційного оголошення;

- суворої необхідності;

- неможливості відступу від деяких прав;

- сумісності з іншими міжнародно-правовими зобов'язаннями;

- недискримінації;

- міжнародного повідомлення.

Дещо інша концепція надзвичайного становища порівняно 3 редакцією Пакту і Конвенції міститься в п. 1 ст. 27 Американської конвенції про права людини (далі - Американська конвенція). У ній відсутня конструкція «життя 
нації», відповідно до цієї норми відступ $є$ правомірним «під час війни, суспільної небезпеки або інших надзвичайних обставин, які загрожують незалежності та безпеці держави-учасниці».

В іншому підхід до права держав-учасниць названого регіонального договору на дерогацію в основному залишається схожим 3 підходом, який знайшов своє закріплення у Пакті та Конвенції, включаючи принципи обмеження дій держав у цій сфері.

Зазначені документи є ключовими міжнародними договорами у галузі прав людини й представлені універсальним і регіональним рівнями. Статті про право держави на відступ від деяких своїх зобов'язань, що містяться в цих договорах, мають трьохчасткову структуру iз схожою змістовною послідовністю. Також усі три наведені документи містять перелік прав людини, відступ за зобов'язаннями стосовно забезпечення яких є неприпустимим за жодних умов.

Згідно 3 п. 2 ст. 4 Пакту положення про відступ не може бути підставою для якихось відступів від статей 6 (право на життя), 7 (заборона катувань чи жорстокого поводження), 8 (заборона рабства) (пункти 1 і 2), 11 (заборона позбавлення волі лише на підставі невиконання договірного зобов'язання), 15 (заборона незаконного визнання винним у вчиненні будь-якого кримінального злочину), 16 (право на правосуб'єктність) і 18 (право на свободу думки, совісті і релігіï).

Так само відповідно до п. 2 ст. 15 Конвенції не припускається відступ від ст. 2 (право на життя), крім випадків смерті внаслідок правомірних воєнних дій, ст. 3 (заборона катувань), ст. 4 п.1 (заборона рабства і підневільного стану), ст. 7 (ніякого покарання без закону).

Найбільш чисельним є перелік статей, за якими не допускається відступ від зобов’язань, закріплений у п. 2 ст. 27 Американської конвенції. Окрім прав, аналогічних до розглянутих вище, зазначена норма доповнює цей перелік ст. 17 (права сім’і), ст. 18 (право на ім’я), ст. 19 (права дитини), ст. 20 (право на громадянство) і ст. 23 (право на участь у державному управлінні). 
Пункт 3 ст. 4 Пакту в усіх наведених нормах закріплює обов'язок держави повідомити головну адміністративну посадову особу відповідної міжнародної організації про використання права на відступ від своїх зобов'язань, про вжиті заходи і причини їх вжиття, а також дату, коли держава припиняє такий відступ.

Договірні положення Свропейської й Американської конвенцій з прав людини передбачають створення судових органів для забезпечення виконання конвенційних зобов'язань і тлумачення змісту конвенцій. Більшість дослідників підкреслюють виключний характер права держави на відступ від зобов'язань, яке, однак, є необхідним для заповнення «правового вакууму», що виникає під час надзвичайного становища (озброєного конфлікту, масових заворушень, природних катастроф або стихійного лиха) [7, с. 3]. Враховуючи виключність права на відступ від зобов'язань, під час тлумачення конвенційних норм, що закріплюють таке право, відповідні судові органи враховують міжнародні стандарти поведінки держав при надзвичайному становищі, керуючись, зокрема, принципом ефективного й динамічного тлумачення.

У межах цієї статті ми розглянемо практику Європейського суду з прав людини (далі - Суд), інтерес до вивчення якої зумовлений ії безпосереднім впливом на сучасну ситуацію в Україні.

Справи, що розглядаються Судом стосовно питання права держави на відступ від зобов'язань, є багатоаспектними, а правова аргументація - дуже докладною. За часів роботи Суду раніше за Україну низка держав - учасниць Конвенції скористалися своїм правом на відступ. Це були Албанія, Вірменія, Франція, Грузія, Греція, Ірландія, Туреччина і Велика Британія. У своїй практиці Суд детально розтлумачив положення ст. 15 Конвенції.

Перш за все право на відступ від зобов'язань може виникати лише під час війни або іншої суспільної небезпеки, що загрожує життю нації. У своєму рішенні у справі Iawless v. Ireland (1961 р.) ${ }^{1}$, звернення за яким стало наслідком

\footnotetext{
${ }^{1}$ https://hudoc.echr.coe.int/eng\#\{ "fulltext":["|"CASE OF LAWLESS v. IRELAND (No. 3)
} 
відступу Ірландією від своїх зобов'язань у 1957 р. у зв'язку з діяльністю IPA та iii дисидентських груп, Суд дійшов висновку, що звичайний зміст слів «інша суспільна небезпека, що загрожує життю нації» достатньо зрозумілий, враховуючи, що: «вони стосуються до виключної кризової ситуації або надзвичайного становища, яке зачіпає все населення i становить загрозу організованому життю співтовариства, яким $є$ ця держава».

У розглянутій справі Суд визнав, що уряд Ірландії обгрунтовано дійшов висновку про існування на той момент «суспільної небезпеки, що загрожує життю нації», виходячи 3 низки таких факторів: існування на території Республіки Ірландія таємної армії, яка займалася неконституційною діяльністю і застосовувала насильство для досягнення своїх цілей; того факту, що ця армія також діяла за межами території держави, таким чином, поставивши під серйозну загрозу відносини Республіки Ірландія 3 iі сусідом; стійкого i тривожного зростання терористичної діяльності починаючи з осені 1956 p. i протягом $1957 \mathrm{p}$.

У своєму рішенні Суд дійшов висновку, що в Ірландії мала місце суспільна небезпека, що загрожувала життю нації, й ірландський уряд мав право застосувати положення ст. $15 \S 1$ Конвенції з метою, задля якої було створено ці положення, і вжити заходів на відступ від свої зобов'язань за Конвенцією.

Тривала нестабільність на території острова Ірландія призвела до того, що у 1970-х рр. Суду довелося знову розглядати ст. 15 Конвенції, але вже в міждержавній справі Ireland v. The United Kingdom $(1978)^{2}$. Розгляд цієї справи став наслідком відступу Сполученого Королівства від своїх зобов'язань на початку 1970-х рр. після терористичних актів, пов'язаних із ситуацією в Північній Ірландії. Зокрема, у зазначеній справі йшлося про законодавство стосовно тероризму, яке Сполучене Королівство застосовувало в Північній Ірландії. 3 метою боротьби 3 «найтривалішою і найнасильницькою кампанією в

\footnotetext{
${ }^{2}$ https://hudoc.echr.coe.int/eng\#\{ "fulltext":["Ireland v. The United Kingdom"],"documentcollectionid2
} 
будь-який частині острову Ірландія», за словами держави-відповідача, влада Північної Ірландії у період з серпня 1971 р. по грудень 1975 р. застосувала низку позасудових повноважень відносно арешту, затримання та інтернування. Протягом вказаного періоду уряд Сполученого Королівства направляв Генеральному секретарю Ради Європи шість повідомлень про відступ, що стосувався цих повноважень. Ірландський уряд стверджував, що позасудові заходи позбавлення волі не є повністю сумісними зі ст. 15 і порушують ст. 5 (право на свободу і особисту недоторканність). На думку Суду, наявність суспільної небезпеки, що загрожує життю нації, була абсолютно очевидною із фактів справи. Суд послався на ті факти, які демонстрували кількість вбитих i поранених у зазначений період у Північній Ірландіiі, а також суму, що становила вартість знищеного майна.

У справі Brannigan and McBride v. the United Kingdom (1993) ${ }^{3}$, яка стосувалася відступу Сполученим Королівством від своїх зобов'язань відносно Північної Ірландії, двох заявників, що підозрювались у членстві в IPA, було арештовано поліцією в Північній Ірландії, вони утримувалися під вартою, не маючи можливості постати перед суддею. Суд, «провівши власну оцінку у світлі матеріалів, які він мав стосовно масштабів і діï терористичного насильства у Північній Ірландії та в інших місцях Сполученого Королівства», знову ухвалив рішення, що не може бути сумнівів у тому, що в період, який розглядається, існувала суспільна небезпека.

Подібною була скарга у справі Marshall v. United Kingdom $(2001)^{4}$, яка була відхилена на стадії прийнятності. Суд погодився із доводами уряду, відзначивши, що влада продовжувала стикатись із загрозою терористичного насильства, незважаючи на зменшення кількості випадків такого насильства. Стосовно спалаху смертоносного насильства протягом тижнів, які передували арешту заявника, Суд зазначив, що це само по собі підтверджує, що після дати

\footnotetext{
${ }^{3}$ https://hudoc.echr.coe.int/eng\#\{ "fulltext":["Brannigan and McBride v. the United Kingdom"],"documentcollectionid2"

${ }^{4}$ https://hudoc.echr.coe.int/eng\#\{ "fulltext":["Marshall v. United Kingdom"],"documentcollectionid2"
}

(C) Чевичалова Ж. В., 2017 
винесення рішення у справі Браннінгана і Макбрайда не було повернення до нормальної ситуації, яке дозволило б Суду оскаржити оцінку владою ситуації у провінції з точки зору загрози, що організоване насильство становило для життя суспільства, та пошуку мирного врегулювання.

Інший характер мала доповідь Свропейської Комісії з прав людини у справі Denmark, Norway, Sweden and the Netherlands v. Greece ("The Greek Case») (1969) ${ }^{5}$. У своїй заяві уряди Даніï, Норвегії, Швеції та Голландії стверджували, що грецький уряд порушив низку положень Конвенції та не продемонстрував, що викладених у ст. 15 умов для відступу від зобов’язань було дотримано. У свою чергу Греція стверджувала, що Свропейська Комісія 3 прав людини не мала компетенцї розглядати ситуацію відповідно до ст. 15 на тій підставі, що вона не могла контролювати дії, за допомогою яких революційний уряд перебував при владі.

Європейська Комісія з прав людини визнала, що вона наділена такою компетенцією і з цих обставин умови для застосування ст. 15 Конвенції не було дотримано. Було встановлено, що законодавчі заходи та адміністративна практика грецького уряду порушили низку положень Конвенції, і що ці заходи та практика не були виправданими в конвенційному розумінні ст. 15.

У 1990 р. після сутичок між силами безпеки і членами нелегальної організації РпК (Робоча партія Курдистану) турецький уряд відступив від своїх зобов’язань відносно південно-східної частини Туреччини. Як наслідок такого відступу в Суді було розглянуто справу Aksoy v. Turkey (1996) ${ }^{6}$.

Урахувавши всі наявні докази, Суд встановив, що масштаби і конкретні наслідки терористичної діяльності РпК у південно-східній частині Туреччини безсумнівно створили в цьому регіоні суспільну небезпеку, що загрожує життю нації. Суд відзначив, зокрема, що кожна Договірна держава, яка несе відповідальність за життя своєї нації, має право визначати, чи загрожує такому життю суспільна небезпека, і якщо так, то як далеко вона може зайти у своїх

\footnotetext{
${ }^{5}$ http://www.echr.coe.int/Documents/Denmark_Norway_Sweden_Netherlands_v_Greece_I.pdf

${ }^{6}$ https://hudoc.echr.coe.int/eng\#\{ "fulltext":["Aksoy v. Turkey"],"documentcollectionid2"
}

(С) Чевичалова Ж. В., 2017 
спробах подолати цю небезпеку. Оскільки національна влада може безпосередньо й постійно спостерігати ситуацію і нагальні потреби, вона, в принципі, має більше можливостей, ніж міжнародний суд, для прийняття рішення як про існування такої суспільної небезпеки, так і про характер i масштаб відступу, необхідного для їі ліквідації. Відповідно національній владі 3 цього питання надається широка свобода розсуду. Втім, держава не користується необмеженою свободою розсуду щодо цього і тому до функцій Суду входить, зокрема, розгляд питання, чи не вийшла держава за межі, «суворо обумовлені гостротою ситуації». Під час здійснення цього європейського нагляду Суд повинен належним чином оцінити такі фактори, як характер прав, яких порушено відступом, обставини, що привели до такого відступу, а також тривалість суспільної небезпеки.

Однак у справі Sakik and Others v. Turkey (1997)7, в якій заявники скаржилися на порушення турецькою владою ст. 5 Конвенції (право на свободу i особисту недоторканність) під час того ж відступу від зобов'язань, що і у вищезазначеній справі, Суд у своєму рішенні дійшов іншого важливого висновку. Відповідно до нього цілям ст. 15 суперечило б, якщо під час оцінки територіального застосування відступу довелося б поширити його наслідки на ту частину турецької території, яка чітко не названа в повідомленні про відступ, що надане Генеральному секретарю Ради Свропи.

Особливий характер має рішення Великої Палати у справі A. And Others v. United Kingdom (2009) $)^{8}$. Скарги заявників випливали 3 дій британського уряду під час відступу Сполученим Королівством від своїх зобов’язань у 2001 р. після терактів 9 вересня 2001 р. у США. Одинадцять заявників скаржилися на те, що вони утримувалися під вартою в режимі підвищеної безпеки відповідно до Закону «Про боротьбу 3 тероризмом, злочинністю i забезпечення безпеки» 2001 р., хоча, за їх твердженням, у зазначений час не існувало жодної суспільної небезпеки, що загрожувала б життю нації. Заявниками було висунуто три

\footnotetext{
${ }^{7}$ https://hudoc.echr.coe.int/eng\#\{"fulltext":["Sakik and Others v. Turkey"],"documentcollectionid2"

${ }^{8}$ https://hudoc.echr.coe.int/eng\#\{ "fulltext":["A. And Others v. United Kingdom"],"documentcollectionid2"
}

(C) Чевичалова Ж. В., 2017 
основних аргументи на захист свого твердження: по-перше, суспільна небезпека не була ані фактичною, ані невідворотною; по-друге, вона не мала тимчасового характеру; по-третє, ні практика інших держав, що відступали від своїх зобов’язань за Конвенцією, ні інформовані думки інших національних i міжнародних органів не дозволяють припустити, що існування суспільної небезпеки було встановлено.

Суд визнав, що суспільна небезпека, що загрожувала життю нації, мала місце. Статс-секретар надав національним судам докази існування загрози серйозних терактів, запланованих проти Сполученого Королівства. Додаткові секретні докази були надані SIAC. Усі національні судді, окрім одного, визнали достовірність цієї загрози. Хоча жодних терористичних атак у Великій Британії на той час, коли був зроблений відступ, не відбулося, Суд не вважає, що національну владу можна звинувачувати у тому, що вона побоювалася таких атак. Неможна вимагати, щоб держава дочекалася катастрофи, перш ніж вжити заходів для боротьби 3 нею. Національна влада користується широкою свободою розсуду під час оцінки загрози на підставі інформації, яка є в іiі розпорядженні. У таких випадках велике значення повинно надаватися думці виконавчої влади і парламенту з цього питання. Також необхідно враховувати думку національних судів, які мають більше можливостей для оцінки доказів, що стосуються існування суспільної небезпеки.

Наступним найважливішим аспектом права держави на відступ $\epsilon$ можливість вживання заходів на відступ від своїх зобов'язань за Конвенцією виключно в межах, яких вимагає гострота становища, i за умови, що такі заходи не суперечать іншим зобов'язанням держави згідно 3 міжнародним правом. Визначальною рисою практики Суду щодо оцінки правомірності заходів, що вживаються державою під час відступу нею від зобов’язань, є детальний аналіз питання про необхідність таких заходів, разом із яким береться до уваги питання гарантій проти зловживань. Незважаючи на те, що норма про право на дерогацію є універсальною і загальновизнаною, на практиці вона відкриває шлях до різноманітних зловживань, які за інших умов могли і повинні мали би 
кваліфікуватися як злочин, та слугує їх заочній легітимації [6, с. 4]. Суд стоїть на тій позиції, що відповідних заходів мають уживати відповідно до «суспільної небезпеки» 3 додержанням принципу територіальності їх дії, їх матеріального змісту і тривалості їх застосування.

Високим Договірним Сторонам Конвенцією надаються широкі межі розсуду під час визначення гостроти становища i суворої необхідності відповідних заходів. Однак разом із тим Суд є правомочним і зобов’язаним проводити свою незалежну оцінку зазначених умов вживання заходів, що передбачають відступ від зобов’язань, які беруться державами-учасницями.

Конвенційне розуміння положень п. 1 ст. 15 випливає 3 практики Суду у справах, що вже були наведені вище. Так, у справі Lawless v. Ireland (1961) Суд відзначив, що жоден 3 доступних ірландському уряду заходів щодо боротьби 3 діяльністю IPA та їі автономних груп, що включали застосування звичайного права і навіть створення спеціальних кримінальних судів, не дозволили б упоратися із ситуацією, яка існувала в Ірландії в 1957 р., та відновити мир і порядок. За таких обставин Суд зазначив, що утримання під вартою осіб, підозрюваних у терористичній діяльності, без того, щоб доставити їх судді, як це передбачено Законом 1940 р., що є предметом низки гарантій, спрямованих на попередження зловживанням в межах цієі системи адміністративного затримання, можна розглядати як захід, суворо обумовлений гостротою ситуації, у розумінні ст. 15 Конвенції.

Щодо рішення у справі Ireland v. the United Kingdom (1978). Суд, зважаючи на те, що 3 цього питання національній владі надається широка свобода розсуду, зауважив, що втім вона не є необмеженою. Тому до функцій Суду входить, зокрема, розгляд питання, чи не вийшла держава за межі заходів, суворо обумовлених гостротою ситуації. У даній справі Суд не вважав встановленим, 3 урахуванням свободи розсуду, що надається Договірним державам, що Сполучене Королівство вийшло за межі заходів, суворо обумовлених гостротою ситуації, у розумінні ст. 15 Конвенції.

У своєму рішенні у справі Branningan and McBride v. United Kingdom 
(1993) Суд дійшов висновку, що з урахуванням обставин справи неможливо стверджувати, що уряд перевищив межі свого розсуду під час прийняття рішення проти судового контролю. Що стосується гарантій проти зловживань, Суд вважає, що такі гарантії дійсно існують і забезпечують ефективний захист від неправомірної поведінки та утримання під вартою без зв'язку із зовнішнім світом. Додатково до основних гарантій, дотримання відповідного законодавства знаходилося під постійним незалежним контролем, i до 1989 р. це законодавство регулярно оновлювалося. Отже, у даній справі, з урахуванням терористичної загрози в Північній Ірландії, обмеженої сфери дії відступу і причин, висунутих на її підтримку, а також існування основних гарантій проти жорстокого поводження, Суд вважав, що британський уряд не перевищив межі розсуду, встановивши, що відступ був суворо обумовлений гостротою ситуації.

Іншим було рішення у справі Aksoy v. Turkey (1996р.). У цій справі відносно тривалості утримання під вартою без судового контролю, Суд відмітив, що уряд Туреччини не надав Суду яких-небудь докладних причин, чому боротьба 3 тероризмом у Південно-Східній Туреччині зробила нездійсненним судове втручання. Суд дійшов висновку, що, хоча і утримання під вартою підозрюваного протягом 14 днів без судового втручання було необхідним, цей період був виключно довгим. Також протягом цього періоду петиціонер був не тільки жертвою свавільного втручання в його право на свободу, він також перебував під ризиком застосування тортур. Щодо гарантій, передбачених правовою системою Туреччини, Суд взяв до уваги безумовно серйозну проблему тероризму на південному сході Туреччини і труднощі, 3 якими стикається держава під час прийняття ефективних заходів щодо боротьби з тероризмом. Проте Суд не впевнений, що надзвичайність обставин вимагала утримання заявника під вартою за підозрою в участі в терористичних злочинах протягом 14 днів або більше у повній ізольованості, без доступу до судді або до інших судових посадових осіб.

У справі A. and Others v. the United Kingdom (2009) Суд у своєму рішенні встановив, зокрема, що вибір урядом і парламентом імміграційного заходу для 
вирішення питань безпеки (реальна і безпосередня загроза терактів після 11 вересня 2001 р.) призвів до неспроможності адекватно вирішити проблему, оскільки неспівмірні й дискримінаційні заходи у формі безстрокового утримання під вартою застосовувалися до однієї групи підозрюваних у тероризмі. Загроза виходила як від британських громадян, так і від іноземних громадян, і не було жодної значної відмінності між потенційно несприятливим впливом утримання під вартою без пред’явлення звинувачення на громадян або на негромадян. Таким чином, Суд визнав, що був порушений п. 1 ст. 5 Конвенції, оскільки заходи, вжиті в межах відступу, були неспівмірними й проводили невиправдану дискримінаційну відмінність між громадянами i негромадянами.

Окремо вирішується питання стосовно вимоги про те, що відступ не повинен суперечити іншим обставинам у зв'язку 3 міжнародним правом. Уперше петиціонери стверджували в Суді, що «офіційне проголошення» надзвичайного стану є важливою умовою правомірності відступу згідно зі ст. 4 Пакту, учасницею якого є Велика Британія, у справі Branningan and McBride $v$. United Kingdom (1993). Оскільки такого проголошення не було, то, на думку заявників, відступ суперечив іншим зобов'язанням Сполученого Королівства згідно 3 міжнародним правом. Також, на думку заявників, проста заява в парламенті не може вважатися «офіційним проголошенням».

Суд відзначив, що заява міністра внутрішніх справ у Палаті общин 22 грудня 1988 р., яка мала офіційний характер і являла собою публічне проголошення намірів уряду стосовно відступу, відповідала поняттю офіційного відступу.

Так само у справі Marshall v. United Kingdom (2001) Суд зазначив, що не знайшов у посиланні заявника на зауваження Комітету з прав людини $\mathrm{OOH}$ нічого, що дозволило б припустити, що уряд (Сполученого Королівства) повинен вважатися таким, що порушив свої зобов'язання за Пактом, продовжуючи діяти на відступ від зобов'язань після 1995 р.

Таким чином, практика Суду демонструє, що за умови ненадання чітких і 
обгрунтованих аргументів відносно наявності невідповідності дій державивідповідача іiі «іншим зобов’язанням 3 міжнародного права», Суд не буде розглядати дану скаргу [5, с. 1078].

Іншою важливою умовою застосування права на відступ є процедурні вимоги. У контексті п. 3 ст. 15 Конвенції будь-яка Висока Договірна Сторона, використовуючи право на відступ від своїх зобов'язань, у повному обсязі інформує Генерального секретаря Ради Свропи про вжиті нею заходи і причини їх вжиття. Вона також повинна повідомити Генерального секретаря Ради Свропи про час, коли такі заходи перестали застосовуватися.

За відсутності такого офіційного і публічного повідомлення відповідно до практики Суду застосування ст. 15 Конвенції є неправомірним. Слід зауважити, що зазначена норма не вимагає, щоб держава, що відступає від своїх зобов’язань, визначала положення, від яких вона відступає. Однак із судової практики, а саме зі справи Iawless v. Ireland (1961) випливає, що повідомлення повинно надходити негайно. У зазначеній справі між застосуванням заходів, ужитих на відступ від зобов'язань, і наданням повідомлення минуло дванадцять днів. При цьому в цій справі Суд дійшов висновку, що уряд надав Генеральному секретарю достатню інформацію про вжиті заходи і причини їх застосування, роз'яснивши у письмовій формі, що ці заходи були вжиті для того, щоб запобігти скоєнню злочинів проти суспільного спокою і порядку й перешкодити збереженню озброєних сил, за винятком сил, які дозволені Конституцією.

Іншим прикладом слугує доповідь Європейської Комісії з прав людини від 4 жовтня 1983 р. у міждержавній справі Cyprus v. Turkey. У зазначеній доповіді Комісія підтвердила висновки, яких дійшла у попередній аналогічній справі, а саме, що Туреччина у відсутності офіційного i публічного повідомлення іiі про відступ від зобов'язань, не могла застосувати ст. 15 Конвенції до заходів, які були вжиті Туреччиною до осіб або майна у північній частині Кіпру. Таким чином, Комісія висловила думку, що Туреччина порушила ст. 5 (право на свободу і особисту недоторканність) і ст. 8 (право на 
повагу до приватного і сімейного життя) Конвенції, в сукупності зі ст. 1 (захист власності) Протоколу № 1 Конвенції.

Щодо обов’язковості надання інформації про вжиті заходи і причини їх вжиття, то практика європейських органів по захисту прав людини дає підстави дійти однозначних висновків.

У своій доповіді у справі Greece v. United Kingdom (1958) 9 Свропейська Комісія з прав людини зазначила, що держава повинна повідомляти про вжиті заходи без зайвих затримань і надавати достатньо інформації для того, щоб Інші Високі Договірні Сторони могли оцінити характер і ступінь відступу, у межах якого цих заходів було вжито. У випадку зазначеної справи тримісячний період між вжиттям заходів у межах відступу i повідомленням був надто довгим, і не може бути виправданим адміністративними затримками, які були викликані припустимою суспільною небезпекою. Окрім того, вербальне повідомлення 3 боку британського уряду не супроводжувалося письмовим описом заходів, вжитих на відступ від зобов'язань за Конвенцією. Однак, визнавши, що п. 3 ст. 15 не містить чітких указівок стосовно інформації, яка повинна міститися у повідомленні, і що розглянуте повідомлення було першим, поданим у рамках цього положення, Комісія не дійшла висновку, що було порушено п. 3 ст. 15. Разом із тим додала, що для задовільної роботи Конвенції дуже важливим є те, щоб інформація, яка надається Високою Договірною Стороною, містила письмовий опис заходів, ужитих відповідно до ст. 15 , як це було вже у справі Iawless v. Ireland.

Суд у рішенні у справі Iawless v. Ireland (1961) постановив, що ірландський уряд виконав свої зобов'язання відповідно до п. 3 ст. 15 Конвенції. Він зазначив, що до листа від 20 червня 1957 р. були додані копії ч. II Закону про злочини проти держави 1940 р. і Прокламації від 5 липня (опублікованої 8 липня), відповідно до якої вона набрала чинності. У листі також пояснювалося, що було вжито відповідних заходів з метою попередження вчинення злочинів

\footnotetext{
${ }^{9}$ hudoc.echr.coe.int/webservices/content/pdf/001
}

(C) Чевичалова Ж. В., 2017 
проти суспільного спокою і порядку, а також попередження підтримки будьяких воєнізованих або озброєних формувань, окрім тих, що дозволені Конституцією. Таким чином, уряд Ірландії надав Генеральному секретарю достатню інформацію про вжиті заходи і причини їх вжиття. Крім того, повідомлення було надано без зволікань.

Необхідною вимогою для застосування ст. 15 Конвенції є дотримання критерію ratione loci. У рішенні у справі Sakik and Others v. Turkey (1997) Суд зазначив, що Постанови, про які згадувалося у повідомленні про відступ, стосувалися лише того регіону, де було проголошено надзвичайний стан, i до якого, згідно із повідомленням про відступ, не входила Анкара. Утім, арешт і утримання заявників під вартою відбулися саме в Анкарі. На думку турецького уряду, це не буде перешкодою для вжиття заходів на відступ від зобов'язань, i ці заходи були продовженням антитерористичної кампанії, яка проводилася на території області у південно-східній частині Туреччини, де було оголошено надзвичайний стан. у цьому рішенні Суд дійшов висновку, що, якщо територіальна сфера дії відступу буде поширюватися на території, які прямо не вказані у повідомленні про відступ, це буде суперечити цілям і завданням ст. 15 Конвенції.

Аналогічних позицій Суд дотримувався і у низці справ проти Туреччини, таких зокрема як Abdulsamet Yaman v. Turkey (2 листопада 2004 p.) ${ }^{10}$, Yurttas v. Turkey (27 травня 2004 р.) $)^{11}$.

Щоб проілюструвати позицію Суду щодо інформації про дату припинення вжиття заходів на відступ від зобов'язань, розглянемо рішення у справі Brogan and Others v. United Kingdom (29 листопада 1988 р.) $)^{12}$. Суд, зокрема, зазначив, що 22 серпня 1984 р. британський уряд проінформував Генерального секретаря Ради Європи, що він відкликає повідомлення про відступ, надане у відповідності із ст. 15 Конвенції з посиланням на суспільну

\footnotetext{
${ }^{10}$ https://hudoc.echr.coe.int/eng\#\{"fulltext":["Abdulsamet Yaman v. Turkey"],"documentcollectionid2".

${ }^{11}$ https://hudoc.echr.coe.int/eng\#\{ "fulltext":["Yurttas v. Turkey"],"documentcollectionid2".

${ }^{12}$ https://hudoc.echr.coe.int/eng\#\{"fulltext":["Brogan and Others v. United Kingdom"],"documentcollectionid2".
}

(C) Чевичалова Ж. В., 2017 
небезпеку в Північній Ірландії. 3 цього випливає, що у даній справі не було жодних підстав розглядати питання про допустимість, згідно зі ст. 15, відступу Сполученого Королівства від зобов’язань за Конвенцією у зв’язку 3 терористичними діями в Північній Ірландії. До справи слід підходити з тих позицій, що всі статті Конвенції, на які посилаються заявники, залишаються повністю застосованими. У цій справі Суд встановив, що було порушено п. 3 ст. 5 Конвенції і визнав, що строк чотири дні і шість годин, чи навіть більше, не може вважатися таким, що відповідає вимогам негайності.

3 огляду на це ми можемо, керуючись принципом правової визначеності, 3 урахуванням сучасного стану справ на території України певним чином спрогнозувати позицію Суду щодо можливих порушень прав людини, пов'язаних із відступом держави від зобов'язань.

Отже, нормативне закріплення права на дерогацію, зокрема у ст. 15 Конвенції, визнає можливість існування об'єктивної потреби у зниженні рівня захисту прав і свобод людини. Одночасно із закріпленням права держави на відступ від зобов’язань зазначені норми містять умови, що покликані запобігти невиправдано широкому застосуванню такого права.

Так, серед основних вимог, які містить ст. 15, по-перше, закріплено те, що право на відступ держави від своїх зобов'язань може виникати тільки за умови наявності війни або іншої суспільної небезпеки, яка загрожує життю нації.

Наступною ключовою вимогою є те, що заходи, яких вживає держава на відступ від своїх зобов'язань, повинні суворо відповідати гостроті становища.

Третьою вимогою є неприпустимість поширення права на відступ на права, захист яких гарантовано статтями, перелік яких наведений у п. 2 ст. 15 Конвенції.

Також ці заходи не повинні суперечити іншим зобов'язанням держави згідно $з$ міжнародним правом.

I безспірною є умова додержання процедурних вимог, закріплених п. 3 ст. 15, щодо офіційного публічного повідомлення про відступ, яке містить 
інформацію про вжиті державою заходи і причини їх вжиття.

Спробуємо з'ясувати відповідність відступу України від своїх зобов'язань наведеним вище вимогам.

У п. 3 Заяви Верховної Ради України «Про відступ України від окремих зобов'язань, визначених Міжнародним пактом про громадянські і політичні права та Конвенцією про захист прав людини і основоположних свобод» [2] зазначається, що триваюча збройна агресія Російської Федерації проти України, яка супроводжується вчиненням воєнних злочинів і злочинів проти людяності як регулярними Збройними силами Російської Федерації, так і незаконними збройними формуваннями, керованими, контрольованими і фінансованими Російською Федерацією, становить суспільну небезпеку, яка загрожує життю нації у розумінні п. 1 ст. 4 Міжнародного пакту про громадянські і політичні права, п. 1 ст. 15 Конвенції про захист прав людини і основоположних свобод.

Пункт 4 зазначеної Заяви закріплює, що з метою забезпечення життєво важливих інтересів суспільства і держави в умовах збройної агресії Російської Федерації органи державної влади України вимушені приймати рішення, які становлять Певний відступ від зобов'язань України за міжнародними договорами у сфері прав людини.

3 викладеного вище вбачається, що наявність суспільної небезпеки, яка загрожує життю нації, яка є першою вимогою для виникнення у держави права на дерогацію, не викликає сумніву.

Щодо другої вимоги, а саме такої, що заходів, які вживає держава на відступ від своїх зобов'язань, повинні суворо відповідати гостроті становища, то у п. п. 5 - 8 Заяви перелічено заходи, яких Україна вживає на відступ. Зокрема, це внесення змін до Закону України «Про боротьбу з тероризмом», відповідно до яких у районі проведення довготривалої антитерористичної операції, як виняток, може здійснюватися превентивне затримання осіб, причетних до терористичної діяльності, на строк понад 72 години, але не більше ніж на 30 діб, за згодою прокурора та без ухвали суду (п. 5).

Пункт 6 Заяви інформує про внесення змін до Кримінального 
процесуального кодексу України щодо особливого режиму досудового розслідування в умовах воєнного, надзвичайного стану або у районі проведення антитерористичної операції. Відповідно до цих змін на час проведення антитерористичної операції повноваження слідчих суддів у досудовому розслідуванні тимчасово передаються відповідним прокурорам, які набувають додаткових процесуальних прав. Особливий режим досудового розслідування діє виключно у районі проведення антитерористичної операції та за умови неможливості слідчого судді виконувати свої повноваження.

Наступним заходом було прийняття Закону України «Про здійснення правосуддя та кримінального провадження у зв’язку 3 проведенням антитерористичної операції» від 12 серпня 2014 р. Відповідно до цього Закону було змінено територіальну підсудність справ (п. 7).

Також було прийнято Закон України/ «ійськово-цивільні адміністрації» від 5 лютого 2015 р., відповідно до якого новоутвореним військово-цивільним адміністраціям в районі проведення антитерористичної операції було надано певних надзвичайних повноважень, які мають тимчасовий характер та елементи військової організації управління. Діяльність таких адміністрацій спрямована на забезпечення безпеки та нормалізації життєдіяльності населення в зоні проведення антитерористичної операції, про що говориться у п. 8 Заяви.

Отже, враховуючи свободу розсуду, що надається державі у вирішенні питання вибору заходів, яких вона вживає на відступ від своїх зобов'язань, Україна внесла зміни до низки нормативних актів з метою запобігання загрозі життю нації, про що проінформувала Генерального секретаря Організації Об’єднаних Націй та Генерального секретаря Ради Свропи.

Щодо неприпустимості поширення права на відступ на права, захист яких гарантовано статтями, перелік яких наведений у п. 2 ст. 15 Конвенції, то Україна у Заяві наводить статті міжнародних договорів з прав людини, на які вона поширює своє право на дерогацію. У п. 9 Україна заявляє про використання свого права на відступ від зобов'язань за п. 3 ст. 3 , статтями 9, 12 , 13, 14 та 17 Міжнародного пакту про громадянські і політичні права та 
статтями 5, 6 і 8 Конвенції про захист прав людини і основоположних свобод. Таким чином, Україна за умов, що склалися, не виключає можливості відступу від гарантування права на свободу та особисту недоторканність, права на справедливий суд, права на повагу до приватного і сімейного життя, права на ефективний засіб юридичного захисту, права на вільне пересування і свободу вибору місця проживання.

3 подальшого тексту заяви вбачається, що перелік прав, за якими Україна не виключає можливість зниження гарантування, не є вичерпним. У п. 10 Заяви проголошується, що Україна залишає за собою право вживати заходів, які можуть бути підставою для відступу від зобов'язань за іншими статтями Пакту і Конвенції на підставі та в порядку, визначених цими документами, про що здійснюватиметься інформування Генерального секретаря Організації Об'єднаних Націй та Генерального секретаря Ради Європи.

3 викладеного вище вбачається, що умова додержання процедурних вимог, закріплених у п. 3 ст. 15 Конвенції щодо офіційного публічного повідомлення про відступ, яке містить інформацію про вжиті державою заходи і причини їх вжиття, є дотриманою у Заяві Верховної Ради України «Про відступ України від окремих зобов'язань, визначених Міжнародним пактом про громадянські і політичні права та Конвенцією про захист прав людини i основоположних свобод» від 21 травня 2015 р.

Слід звернути увагу на територіальний і тимчасовий характер права на відступ від зобов'язань, який випливає з Конвенції і практики Суду.

Нагадаємо, що у рішенні у справі Sakik and Others v. Turkey (1997) Суд установив необхідність додержання територіального принципу дії права на відступ. Оскільки, якщо територіальна сфера відступу буде поширюватися на території, які явно не зазначені у повідомленні про відступ, це буде суперечити цілям і завданням ст. 15 Конвенції.

3 огляду на це зазначимо, що в Постанові Верховної Ради України «Про Заяву Верховної Ради України «Про відступ України від окремих зобов’язань, визначених Міжнародним пактом про громадянські і політичні права та 
Конвенцією про захист прав людини і основоположних свобод» від 21 травня 2015 р. (далі - Постанова) [4] і у самій Заяві йдеться про безпекову ситуацію в Донецькій та Луганській областях, про стан якої Україна зобов'язується інформувати Генерального секретаря ООН та Генерального секретаря Ради Європи, а також про зміну території, на яку поширюється відступ України від своїх зобов’язань.

Відповідно до п. 1 Заяви у зв’язку з анексією та тимчасовою окупацією Російською Федерацією невід’ємної частини території України - Автономної Республіки Крим та міста Севастополя, здійсненої внаслідок збройної агресії проти України, повну відповідальність за дотримання прав людини і виконання відповідних міжнародних договорів на анексованій та тимчасово окупованій території України несе Російська Федерація.

Щодо тимчасового характеру заходів, що вживаються на відступ від зобов'язань, то, хоча прямого формулювання такої вимога не міститься у ст. 15 , вона випливає 3 ї змісту, а саме «Під час війни або іншої суспільної небезпеки...» (п. 1). I опосередковано 3 вимоги повідомити Генерального секретаря Ради Свропи про час, коли такі заходи перестали застосовуватися, а положення Конвенції знову застосовуються повною мірою (п. 3) [3, с. 221]. Про тимчасовість права на дерогацію свідчить і практика Суду, зокрема, розглянута вище справа Brogan and Others v. United Kingdom (1988).

Ураховуючи таку вимогу, зазначимо, що тимчасовість вжиття заходів на відступ від зобов'язань закладено в П. 1 Постанови, який закріплює, що Україна заявляє про свій відступ від окремих зобов'язань на період до повного припинення збройної агресії Російської Федерації, а саме до моменту виведення усіх незаконних збройних формувань, керованих, контрольованих i фінансованих Російською Федерацією, російських окупаційних військ, їх військової техніки з території України, відновлення повного контролю України за державним кордоном України, відновлення конституційного ладу та порядку на окупованій території України.

Додержанню наведених вище вимог буде служити діяльність 
тимчасового консультативно-дорадчого органу Кабінету Міністрів України Міжвідомчої комісії з питань відступу України від зобов'язань за Міжнародним пактом про громадянські і політичні права та Конвенцією про захист прав людини i основоположних свобод, яку було утворено 19 квітня 2017 p. відповідно до Постанови Кабінету Міністрів України.

Основними завданнями Комісії $\epsilon$ : розгляд питань, пов’язаних із територіальним застосуванням положень щодо відступу України від зобов'язань за Пактом та Конвенцією, а також розгляд актуалізованої інформації про стан безпекової ситуації (ескалація/деескалація ситуації, особливості оперативно-військової ситуації, соціально-економічні аспекти, застосування законів та нормативно-правових актів, які містять положення, що відступають від зобов’язань за Пактом та Конвенцією) та ситуації у галузі прав людини в районі зони проведення антитерористичної операції.

Відповідно до покладених на неї завдань Комісія, зокрема:

- проводить моніторинг та подає Кабінету Міністрів України пропозиції щодо внесення змін до переліку населених пунктів, де органи державної влади тимчасово не здійснюють своїх повноважень;

- визначає механізм оцінювання рівня/дотримання прав людини на території населених пунктів, які перейшли під контроль органів державної влади внаслідок ї звільнення;

- проводить аналіз нормативно-правових актів щодо наявності в них положень, що відступають від окремих зобов’язань України у сфері прав людини, подає Кабінету Міністрів України пропозиції щодо змін до них, визнання їх такими, що втратили чинність, зупинення їх дії тощо, а також у разі потреби пропозиції щодо відповідного інформування Генерального секретаря ООН та Генерального секретаря Ради Свропи та ін.

Висновки. Діяльність Комісії сприятиме запобіганню зловживанням державою правом на відступ від окремих зобов'язань, визначених Пактом та Конвенцією, і невиправданому зниженню рівня захисту прав і свобод людини під час використання Україною такого права. Разом із тим, як зазначено в 
літературі [1, с. 64], з огляду на практику Суду можна порадити заявникам формулювати відповідні скарги навіть у ситуаціях, в яких вони покриваються відступом України від зобов’язань, оскільки саме Суд зрештою дасть оцінку такому відступу та необхідності вжиття тих чи інших заходів в умовах, що існують на окупованих територіях України та в деяких районах проведення антитерористичної операції.

\section{Список літератури:}

1. Європейський суд 3 прав людини, Європейська конвенція 3 прав людини та індивідуальні заяви: перше знайомство. URL: http://www.osce.org/uk/ukraine/232776? download=true (дата звернення: 17.10.2017).

2. Заява Верховної Ради України «Про відступ України від окремих зобов'язань, визначених Міжнародним пактом про громадянські і політичні права та Конвенцією про захист прав людини і основоположних свобод». URL: http://zakon3.rada.gov.ua/laws/show/46219 (дата звернення: 17,10.2017).

3. Комментарий к Конвенции о защите прав человека и основных свобод и практике ее применения / под. общ. ред. В. А. Туманова и Л. М. Ентина. Москва: Норма, 2002. 336 с.

4. Про Заяву Верховної Ради України «Про відступ України від окремих зобов’язань, визначених Міжнародним пактом про громадянські і політичні права та Конвенцією про захист прав людини і основоположних свобод: Постанова Верховної Ради України від 21.05.2015 p. URL: http://zakon3.rada.gov.ua/laws/show/462-19 (дата звернення: 17.10.2017).

5. Права человека при отправлении правосудия: Пособие по правам человека для судей, прокуроров и адвокатов. Серия документов по вопросам профессиональной подготовки № 9. URL: legalspace.org (дата звернення: 17.10.2017).

6. Золотарев М. В., Энтин М. Л. Право на дерогацию в практике применения Европейской конвенции о защите прав человека и основных свобод. Обзор / отв. ред. Ю. С. Пивоваров. Москва: Изд-во ИНИОН АН СССР, 1991. 42 с.

7. Симонова Н. С. Отступление от выполнения обязательств по международным договорам о правах человека в контексте добросовестности трасли права. URL: отраслиправа.рф (дата звернення: 17.10.2017).

8. Христова Г. О. Про позитивні зобов'язання держави в умовах збройного та тимчасової втрати контролю над частиною своєї території. Вісник Національної академії правових наук Украӥни. Харків: Право, 2017. № 2 (89). С. 54-67.

\section{References:}

1. Ievropeiskyi sud z prav liudyny, Yevropeiska konventsiia z prav liudyny ta indyvidualni zaiavy: pershe znaiomstvo. URL: http://www.osce.org/uk/ukraine/232776?download=true [in Ukrainian].

2. Zaiava Verkhovnoi Rady Ukrainy «Pro vidstup Ukrainy vid okremykh zobov'iazan, vyznachenykh Mizhnarodnym paktom pro hromadianski i politychni prava ta Konventsiieiu pro zakhyst prav liudyny i osnovopolozhnykh svobod». URL: http://zakon3.rada.gov.ua /laws/show/462-19 [in Ukrainian].

3. Tumanov, V.A., Entin, L.M. (Eds.). (2002). Kommentarij k Konvencii o zashhite prav cheloveka i osnovnyh svobod i praktike ee primenenija. Moscow: Norma [in Russian].

4. Pro Zaiavu Verkhovnoi Rady Ukrainy «Pro vidstup Ukrainy vid okremykh zobov’iazan, vyznachenykh Mizhnarodnym paktom pro hromadianski i politychni prava ta Konventsiieiu pro zakhyst prav liudyny i osnovopolozhnykh svobod: Postanova Verkhovnoi Rady Ukrainy vid 21.05.2015 r. (2015). URL: http://zakon3.rada.gov.ua/laws/show/462-19. 
5. Prava cheloveka pri otpravlenii pravosudija: Posobie po pravam cheloveka dlja sudej, prokurorov i advokatov. Serija dokumentov po voprosam professional'noj podgotovki № 9. URL: legalspace.org.

6. Zolotarev, M.V., Jentin, M.L. (1991). Pravo na derogaciju v praktike primenenija Evropejskoj konvencii o zashhite prav cheloveka i osnovnyh svobod. Obzor, Ju.S. Pivovarov (Ed.). Moscow: Izd-vo INION AN SSSR [in Russian].

7. Simonova, N.S. Otstuplenie ot vypolnenija objazatel'stv po mezhdunarodnym dogovoram o pravah cheloveka v kontekste dobrosovestnosti trasli prava. URL: otrasli-prava.rf [in Russian].

8. Khrystova, H.O. (2017). Pro pozytyvni zobov'iazannia derzhavy v umovakh zbroinoho ta tymchasovoi vtraty kontroliu nad chastynoiu svoiei terytorii. Visnyk Natsionalnoi akademii pravovykh nauk Ukrainy. Kharkiv: Pravo, 2 (89), 54-67 [in Ukrainian].

Чевычалова Ж. В. Правовые основания отступления Украины от отдельных обязательств, определенных Международным пактом о гражданских и политических правах и Конвенцией о защите прав человека и основных свобод.

Статья посвящена отступлению Украинь от отдельных обязательств, определенных Международным пактом о гражданских и политических правах и Конвенцией о защите прав человека и основных свобод. Рассмотрены правовые основания отступления государства от отдельных обязательств по международным договорам о правах человека, а также соответствие отступления Украины от обязательств условиям, вытекаюшим из Конвенции и практики Европейского суда по правам человека.

Ключевые слова: защита прав человека; отступление государства от обязательств во время чрезвычайного положення; право на дерогацию.

Chevychalova $Z$. V. The legal grounds for derogation of Ukraine from some obligations, which are defined by the International Covenant on Civil and Political Rights and the Convention for the Protection of Human Rights and Fundamental Freedoms.

The article is devoted to the derogation of Ukraine from some obligations, which are defined by the International Covenant on Civil and Political Rights and the Convention for the Protection of Human Rights and Fundamental Freedoms. In this article author is considering the legal grounds for derogation of state from some obligations, which are defined by the international human rights treaties and conformity of derogation of Ukraine from some obligations to the conditions, which are derive from the Convention and practice of the European Court of Human Rights.

Keywords: protection of human rights; derogation in time of emergency Convention for the Protection of Human Rights and Fundamental Freedoms; right to a derogation.

Надійшла до редколегії 20.11.2017 p. 